\title{
Effects of levels of potassium and nitrogen on yields and post-harvest conservation of onions in winter
}

\author{
Geraldo Milanez de Resende ${ }^{1}$, Nivaldo Duarte Costa ${ }^{2}$ \\ http://dx.doi.org/10.1590/0034-737X201461040018
}

\begin{abstract}
Potassium and nitrogen are the elements present in the highest percentage in the onion dry matter. The objective of this experiment was to evaluate yield and post-harvest conservation of Vale Ouro IPA-11 onion cultivar regarding to nitrogen and potassium levels. The experiment was carried out in Petrolina-PE, Brazil, from June to September 2009. The experimental design was a completely randomized block in a 4 x 3 factorial design, composed of four nitrogen levels $(0$, 60,120 and $\left.180 \mathrm{~kg} \mathrm{ha}^{-1}\right)$ and three potassium levels $\left(0,90\right.$ and $\left.180 \mathrm{~kg} \mathrm{ha}^{-1}\right)$ with three replications. The highest yield of commercial bulbs was achieved at an estimated $\mathrm{N}$ level of $172.6 \mathrm{~kg} \mathrm{ha}^{-1}$. The lowest yield of noncommercial bulbs was estimated at $\mathrm{N}$ level of $147.0 \mathrm{~kg} \mathrm{ha}^{-1}$. Lower percentage of smaller bulbs (class 2) were obtained by increasing levels of $\mathrm{N} x \mathrm{~K}$, with a quadratic effect at the dose of $90 \mathrm{~kg} \mathrm{ha}^{-1} \mathrm{~K}_{2} \mathrm{O}$ and minimum production point with $127.6 \mathrm{~kg} \mathrm{~N} \mathrm{ha}^{-1}(20.3 \%)$. Regarding larger caliber bulbs (class 4), linear effects were found both in the absence and for the level of $90 \mathrm{~kg} \mathrm{ha}^{-1}$ of $\mathrm{K}_{2} \mathrm{O}$ as levels of $\mathrm{N}$ were increased. When the highest level of $180 \mathrm{~kg} \mathrm{ha}^{-1} \mathrm{~K}_{2} \mathrm{O}$ was applied, the level of $92.8 \mathrm{~kg} \mathrm{ha}^{-1}$ of N was estimated as the one that would promote the highest bulb yield of this class (35.4\%), and 5.3\% was found in the lack of potassium fertilization.
\end{abstract}

Key words: Allium cepa, yield, nutrition, storage.

\section{RESUMO}

\section{Efeitos de doses de nitrogênio e potássio na produtividade e conservação pós-colheita da cebola no inverno}

Os elementos presentes, em maior percentagem, na matéria seca da cebola são potássio e nitrogênio. Com o objetivo de avaliar a produtividade e conservação pós-colheita do cultivar de cebola Vale Ouro IPA-11, em função de doses de nitrogênio e potássio, foi conduzido experimento, de junho a dezembro de 2009, em Petrolina-PE. O delineamento experimental foi o de blocos ao acaso, no esquema fatorial 4x3, compreendendo quatro doses de nitrogênio ( 0 ; $60 ; 120$ e $\left.180 \mathrm{~kg} \mathrm{ha}^{-1}\right)$ e três doses de potássio $\left(0 ; 90\right.$ e $\left.180 \mathrm{~kg} \mathrm{ha}^{-1}\right)$, com três repetições. A maior produtividade comercial de bulbos foi estimada com a dose de $172,6 \mathrm{~kg} \mathrm{ha}^{-1} \mathrm{de} \mathrm{N}$. A menor produção de refugos foi obtida com a dose de 147,0 $\mathrm{kg} \mathrm{ha}^{-1}$ de N. Menor percentual de bulbos menores (classe 2) foram obtidos com o aumento das doses de $\mathrm{N}$ e $\mathrm{K}$, ocorrendo, para a dose de $90 \mathrm{~kg} \mathrm{ha}^{-1}$ de $\mathrm{K}_{2} \mathrm{O}$, efeito quadrático, com ponto de mínima produção com $127,6 \mathrm{~kg} \mathrm{ha}{ }^{-1}$ de N (20,3\%). Com relação a bulbos de maior calibre (classe 4), foram obtidos efeitos lineares, tanto na ausência quanto com a dose de $90 \mathrm{~kg} \mathrm{ha}^{-1}$ de $\mathrm{K}_{2} \mathrm{O}$, com o incremento das doses de N. Quando se aplicou a dose maior, de $180 \mathrm{~kg} \mathrm{ha}^{-1} \mathrm{de} \mathrm{K}_{2} \mathrm{O}$, estimou-se a dose de $92,8 \mathrm{~kg} \mathrm{ha}^{-1}$ de $\mathrm{N}$ como a que promoveria a maior produção de bulbos dessa classe $(35,4 \%)$, verificando-se 5,3\%, com a ausência da adubação potássica.

Palavras-chave: Allium cepa, rendimento, nutrição, armazenamento.

Received: March 20th, 2013; approved: July 17th, 2013.

${ }_{1}^{1}$ Agronomist, Doctor of Science. Embrapa - Centro de Pesquisa Agropecuária do Trópico Semiárido, Caixa Postal 23, 56300-970, Petrolina, Pernambuco, Brazil. geraldo.milanez@embrapa.br (corresponding author).

${ }^{2}$ Agronomist, Master of Science. Embrapa - Centro de Pesquisa Agropecuária do Trópico Semiárido, Caixa Postal 23, 56300-970, Petrolina, Pernambuco, Brazil. nivaldo.costa@embrapa.br 


\section{INTRODUCTION}

Among vegetables, onion (Allium cepa) ranks third place in economic importance in Brazil. In 2011, the Brazilian average yield was $22.6 \mathrm{t} \mathrm{ha}^{-1}$, whereas, in the states of Pernambuco and Bahia, the largest producers in the Northeast, the average yield of 20.2 and $21.4 \mathrm{t} \mathrm{ha}^{-1}$, were achieved, respectively (IBGE, 2012).

Nitrogen (N) contributes markedly to improving the production of onion, being absorbed in large amounts, exceeded only by potassium (K) (Porto et al., 2007, May et al., 2008). Besides photosynthesis, $\mathrm{N}$ takes place in other physiological processes vital to the life cycle of plants, such as ion absorption, respiration, cell multiplication and differentiation and inheritance (Epstein $\&$ Bloom, 2006). The beneficial effect of potassium can be found in different traits of agricultural products, such as color, acidity, resistance to shipping, handling and storage, nutritional value and industrial qualities (Malavolta, 2006). Although onions extract large amounts of potassium, in general, responses by the crop to this nutrient have not been found (Filgueira, 2008) and there are few results that confirm a significant effect of $\mathrm{K}$ fertilizer on the yield.

With respect to K fertilization, Kumar et al. (2001), working with the cultivar Pusa Madhavi, reported an increase in onion yield by applying $40 \mathrm{~kg} \mathrm{ha}^{1}$ of $\mathrm{K}_{2} \mathrm{O}$ and lack of response to levels of 80 and $160 \mathrm{~kg} \mathrm{ha}^{1}$, as well as an increase in diameter and fresh matter of the bulb, with the application of $60 \mathrm{~kg} \mathrm{ha}^{1}$ of $\mathrm{K}_{2} \mathrm{O}$, for Nasik Red cultivar (Mohanty \& Das, 2001). Akhtar et al. (2002), when studying five cultivars (Phulkara, Burgundy, White Creole, Swat and Texas Early Grano), found that the application of $200 \mathrm{~kg} \mathrm{ha}^{-1} \mathrm{~K}_{2} \mathrm{O}$ increased yield of onion bulbs, and lowest yields were shown by all cultivars in the lack of $\mathrm{K}$ fertilization.

As for the response of this crop to levels of $\mathrm{N}$, different authors found that the nutrient contributes markedly to increase yield. Kumar et al. (2001) found that the yield of onion bulbs responded significantly to $\mathrm{N}$ application up to $120 \mathrm{~kg} \mathrm{ha}^{1}$. Larger diameter, weight and yield of bulbs were achieved by Mohanty \& Das (2001), also with 120 $\mathrm{kg} \mathrm{ha}^{-1}$ of $\mathrm{N}$, not differing from the results achieved with levels of $90 \mathrm{~kg} \mathrm{~h}^{-1} \mathrm{~N}$. However, Yadav et al. (2003) found that for the cultivar Agrifound Dark Red, the application of $100 \mathrm{kgha}^{-1} \mathrm{~N}$ produced significantly higher yields than the dose of $50 \mathrm{~kg} \mathrm{~N} \mathrm{ha}^{-1}$ and the application of $150 \mathrm{~kg} \mathrm{ha}^{-1}$ $\mathrm{N}$ did not increase the yield of bulbs, in relation to $100 \mathrm{~kg}$ $\mathrm{ha}^{-1} \mathrm{~N}$. When evaluating cultivar Vision, Shock et al. (2004) did not found a positive effect on the total and commercial yield for the level equal to or higher than $145 \mathrm{~kg} \mathrm{ha}^{-1}$ of $\mathrm{N}$.

The objective of this study was to evaluate the effects of nitrogen and potassium on yield and post-harvest quality of onion, grown in the winter, in São Francisco Valley.

\section{MATERIAL AND METHODS}

The experiment was set and carried out from June to September 2009 at the Experimental Field of Bebedouro, Petrolina (9 $9^{\prime}$ S, 40²9' W, 365.5 above sea level). According to the Köppen climate classification, the climate of the region is BSWh', semiarid. The values of annual averages of climatological variables are as follow: air temperature $=26.5^{\circ} \mathrm{C}$; rainfall $=541.1 \mathrm{~mm}$, air relative humidity $=65.9 \%$, class A evaporation pan $=2500 \mathrm{~mm}$ and speed wind $=2.3 \mathrm{~m} \mathrm{~s}^{-1}$. Rainfall is unevenly distributed in space and time, with higher averages in the months from December to April; the annual insolation is higher than 3,000 h (Azevedo et al., 2006). The soil was classified as Oxysol (Santos et al., 2006.), $\mathrm{pH}\left(\mathrm{H}_{2} \mathrm{O}\right)=6.6 ; \mathrm{Ca}=1.8$ $\mathrm{cmol}_{\mathrm{c}} \mathrm{dm}^{-3} ; \mathrm{Mg}=0.6 \mathrm{cmol}_{\mathrm{c}} \mathrm{dm}^{-3} ; \mathrm{Na}=0.01 \mathrm{cmol}_{\mathrm{c}} \mathrm{dm}^{-3} ; \mathrm{K}=$ $0.48 \mathrm{cmol} \mathrm{dm}_{\mathrm{c}}^{-3} ; \mathrm{Al}=0.00 \mathrm{cmol}_{\mathrm{c}} \mathrm{dm}^{-3}, \mathrm{P}($ Mehlich $)=25.0 \mathrm{mg}$ $\mathrm{dm}^{-3}$ and O.M. $=3.6 \mathrm{~g} \mathrm{~kg}^{-1}$. Cultivar Golden Valley IPA-11 was used in the experiment.

The experimental plot consisted of eight 3.0-m long rows, spaced by $0.15 \mathrm{~m}$, with $0.10 \mathrm{~m}$ between plants, with a total area of $3.6 \mathrm{~m}^{2}(3.0 \times 1.2 \mathrm{~m})$ area. The six central rows were used as the useful area, subtracting $0.50 \mathrm{~m}$ at each edge $\left(1.80 \mathrm{~m}^{2}\right)$. Fertilization consisted of the application of $135.0 \mathrm{~kg} \mathrm{P}_{2} \mathrm{O}_{5} \mathrm{ha}^{-1}$ as superphosphate at planting. Nitrogen and potassium fertilization were split into three times. The first fertilization was carried out on planting (1/ 3 ) and the rest (2/3) as two side dressing fertilizations on days 25 and 50 after transplanting. Urea and potassium chloride were used as sources of nitrogen and potassium, respectively.

Soil preparation consisted of plowing, harrowing and beds raised at beds $0.20 \mathrm{~m}$. Seedlings transplanting occurred on day 30 after sowing (May). The irrigations were applied by sprayer, with two-day shift and $9 \mathrm{~mm}$ of water depth, calculated as a function of the class A evaporation pan. The phytosanitary treatments were common to the onion crop.

Onions were harvested in August, when the plants showed signs of advanced senescence, as yellowing and dry leaves, and when more than $70 \%$ of the plants were found dead. Curing was carried out in the field for three days, followed by 12 days in a shaded ventilated barn. The cured bulbs were stored for a period of 60 days.

It was evaluated the yields of commercial (perfect bulbs with cross diameter above $35 \mathrm{~mm}$ ) and noncommercial (waste, less than $35 \mathrm{~mm}$ diameter) bulbs, expressed in $\mathrm{tha}^{-1}, 15$ days after curing. The average fresh mass of bulb (g. bulb $\left.{ }^{-1}\right)$ was determined by dividing the total mass of commercial bulbs, after curing, by the number of bulbs. The 
classification of commercial bulbs, in percentages, according to the cross-sectional diameter $(\mathrm{mm})$ was made in Class 2: greater than 35 to $50 \mathrm{~mm}$ in diameter; Class 3: greater than 50 to $70 \mathrm{~mm}$; Class 4: greater than 70 to $90 \mathrm{~mm}$ and Class 5: greater than $90 \mathrm{~mm}$ (Resende et al., 2009). Percentage data were transformed into $\sqrt{\mathrm{P} / 100}$ arcsine, for effects of statistical analysis.

The experimental design was a randomized block in $4 \times 3$ factorial arrangement, comprising four levels of nitrogen $\left(0,60,120\right.$ and $\left.180 \mathrm{~kg} \mathrm{ha}^{-1}\right)$ and three doses of potassium $\left(0,90\right.$ and $\left.180 \mathrm{~kg} \mathrm{ha}^{-1}\right)$, with three replications. The data collected were submitted to analysis of variance and regression, based on the polynomial model, using the $\mathrm{F}$ test for comparison at $5 \%$ of probability. The levels nitrogen and potassium were adjusted to polynomial regression equations, adopting the significant effect by $\mathrm{F}$ test at $5 \%$ probability as a criterion for choosing the model and the magnitude of the coefficients of determination, using the SISVAR 5.0 program (Ferreira, 2010).

\section{RESULTS AND DISCUSSION}

The results evidenced significant effects for the levels of nitrogen and potassium, as well as for $\mathrm{N} \mathrm{x} \mathrm{K} \mathrm{interaction,}$ varying according to the characteristics evaluated.

For commercial yield, a significant effect was found only for the levels of $\mathrm{N}$. The highest commercial yield (65.7 $\mathrm{t} \mathrm{ha}^{-1}$ ) was estimated from the dose of $172.6 \mathrm{~kg} \mathrm{~N} \mathrm{ha}^{-1}$ (Figure 1). These results are consistent with those found by different authors, who obtained positive responses of $\mathrm{N}$ application on onion crops, up to doses of $150 \mathrm{~kg} \mathrm{ha}^{-1}$ (Diaz-Perez et al., 2003; Singh et al. 2004) and $200 \mathrm{~kg} \mathrm{ha}^{-1}$ $\mathrm{N}$ (Neeraja et al., 2001).

Similar results were found for production of waste (noncommercial bulbs), in which significant effect was found only for doses of N (Figure 2). A gradual reduction IN the production of non-commercial bulbs was found when doses of $\mathrm{N}$ were increased. The lowest production of waste was estimated with the dose of $147.0 \mathrm{~kg} \mathrm{ha}^{-1} \mathrm{~N}\left(1.30 \mathrm{tha}^{-1}\right)$. These results show the responsiveness of the onion to nitrogen application and confirm the statements of different authors, who report that the element contributes markedly to greater yield of this crop, especially in the production of larger bulbs. Ghaffoor et al. (2003) reported lower yields of waste with the increase in NPK fertilization. Lee et al. (2003) and Mandira \& Khan (2003) also reported that these elements contribute markedly to better crop productivity, especially in the production of larger bulbs

Concerning to bulb fresh mass, an effect was found only for the levels of $\mathrm{N}$ (Figure 3). The increase in the levels of the fertilizers caused a linear increase in fresh mass of the bulbs. These results display the positive effects of $\mathrm{N}$ in increasing the fresh mass of the bulb, and they agree with the statements of different authors that the element contributes markedly to produce larger bulbs (Hussaini et al., 2000; Lee et al., 2003; Mandira \& Khan, 2003).

The classification of commercial onion bulbs was influenced by the interaction of the evaluated factors $(\mathrm{N}$ $\mathrm{x}$ K) for the different classes (Table 1). As for the bulbs of smaller size (greater than 35 to $50 \mathrm{~mm}$ in diameter) it was found a linear reduction in total class 2 bulbs 2 in the lack potassium fertilization, given by the negative angular coefficient $(-a)$ of the linear equation $(Y=a x+b)$. That is, in these cases, the higher the nitrogen fertilization, the fewer the Class 2 bulbs. Similar results were obtained for the $180 \mathrm{~kg} \mathrm{ha}^{-1} \mathrm{~K} 2 \mathrm{O}$, for which it was found $55.2 \%$ of class 2 bulbs against $24.8 \%$ with the highest dose (180 $\mathrm{kg} \mathrm{N} \mathrm{ha}^{-1}$ ) for the lack of N. For the level of $90 \mathrm{~kg} \mathrm{ha}^{-1}$ $\mathrm{K}_{2} \mathrm{O}$, a quadratic effect with the point of minimum production with $127.6 \mathrm{~kg} \mathrm{~N} \mathrm{ha}^{-1}$ (20.3\% of small bulbs) was found, obtaining the value of $25.9 \%$ for the maximum

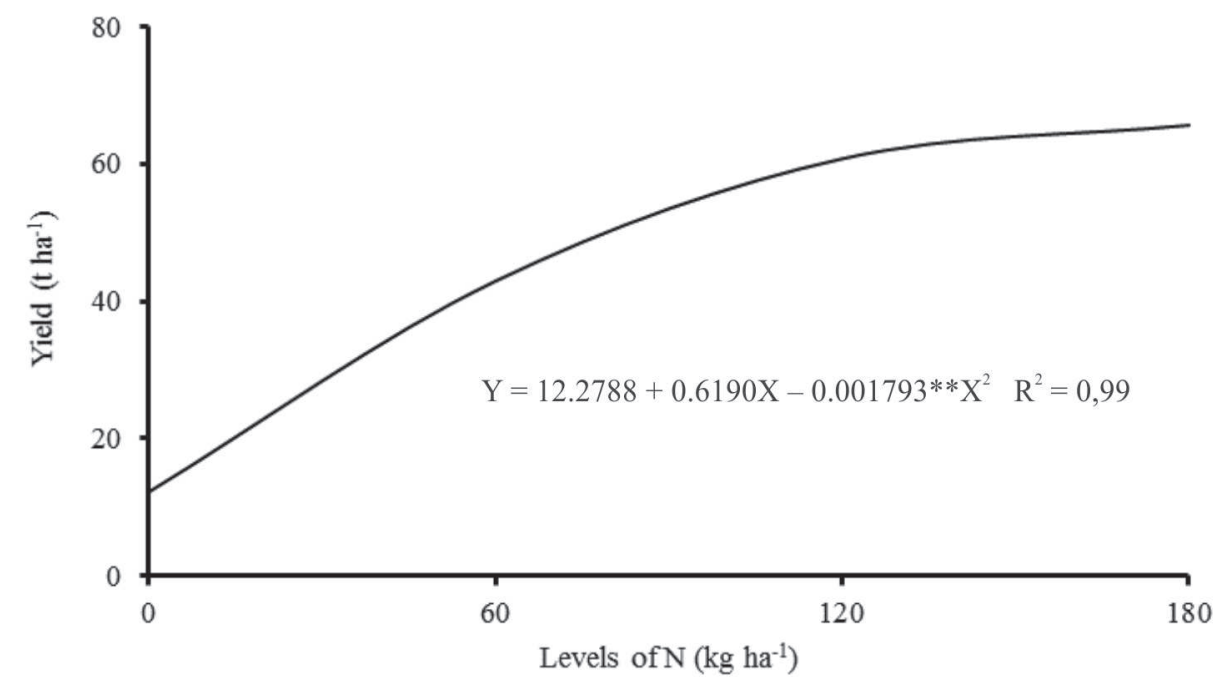

Figure 1. Onion bulbs yields according to N levels. Petrolina-PE, Embrapa Semiárido, 2009.

Rev. Ceres, Viçosa, v. 61, n.4, p. 572-577, jul/ago, 2014 
dose of $\mathrm{N}, 180 \mathrm{~kg} \mathrm{ha}^{-1}$ of $\mathrm{K}_{2} \mathrm{O}$ and $50.8 \%$ for the control, considered as small bulbs. Due to the figures presented, it is inferred that the level of $90 \mathrm{~kg} \mathrm{ha}^{-1} \mathrm{~K}_{2} \mathrm{O}$ is the most economical and with the lowest percentage of smaller bulbs, in the presence of $\mathrm{N}$, compared with the highest dose of potassium applied $\left(180 \mathrm{~kg} \mathrm{ha}^{-1}\right.$ of $\left.\mathrm{K}_{2} \mathrm{O}\right)$.

For Class 3, bulbs that are intermediate in size (greater than 50 to $70 \mathrm{~mm}$ in diameter), a positive linear effect was found when zero potassium was applied. The maximum production of intermediate bulbs for $90 \mathrm{~kg} \mathrm{ha}^{-1} \mathrm{~K}_{2} \mathrm{O}$ occurred by applying $120.0 \mathrm{~kg} \mathrm{ha}^{-1} \mathrm{~N}(63.4 \%)$, that is, by increasing the levels of nitrogen, higher percentages of larger size bulbs was achieved, compared with those obtained with the lack of $\mathrm{K}$ fertilization, which reached $39.6 \%$ (Table 1). A quadratic effect was also found when $180 \mathrm{~kg} \mathrm{ha}^{-1} \mathrm{~K}_{2} \mathrm{O}$ was applied; however, at the point of minimum production at the dose of $50.0 \mathrm{~kg} \mathrm{ha}^{-1} \mathrm{~N}(31.1 \%)$ but when the maximum dose of $\mathrm{N}\left(180 \mathrm{~kg} \mathrm{~N} \mathrm{ha}^{-1}\right)$ was used, $63.8 \%$ was achieved, a result similar to that found with the intermediate dose of $90 \mathrm{~kg} \mathrm{ha}^{-1}$ of $\mathrm{K}_{2} \mathrm{O}$, so the most appropriate for production of bulbs of that class.
As for larger caliber bulbs, (class 4), linear effects were found when zero potassium fertilizer was used. For $90 \mathrm{~kg}$ $\mathrm{ha}^{-1} \mathrm{~K}_{2} \mathrm{O}$, results similar to those obtained with increasing doses of $\mathrm{N}$ were found, for which $30.4 \%$ of bulbs of that class was obtained when the highest dose $\left(180 \mathrm{~kg} \mathrm{ha}^{-1} \mathrm{~N}\right)$ was applied. When the highest dose of $180 \mathrm{~kg} \mathrm{ha}^{-1} \mathrm{~K}_{2} \mathrm{O}$ was applied, the dose of $92.8 \mathrm{~kg} \mathrm{ha}^{-1}$ was estimated as the one that would promote the highest yield of bulbs of that class $(35.4 \%)$, that is, higher nitrogen doses would promote lower percentage of bulbs of that caliber at the highest level of $\mathrm{K}$, which are values slightly higher than those found when the intermediate level of potassium $\left(90 \mathrm{~kg} \mathrm{ha}^{-1} \mathrm{~K}_{2} \mathrm{O}\right)$ was used. By analyzing the results obtained in the three classes of bulbs, it can be inferred that the dose of $90 \mathrm{~kg}$ $\mathrm{ha}^{-1}$ of $\mathrm{K}_{2} \mathrm{O}$ provided the best responses in interaction with nitrogen fertilization.

When such results are evaluated, what can be found in relation to the diameter of the bulbs, in the different classes, is that the $\mathrm{N} \times \mathrm{K}$ interaction provides, depending on the combination of these nutrients, in general, larger and intermediate caliber bulbs (classes 3 and 4), with a

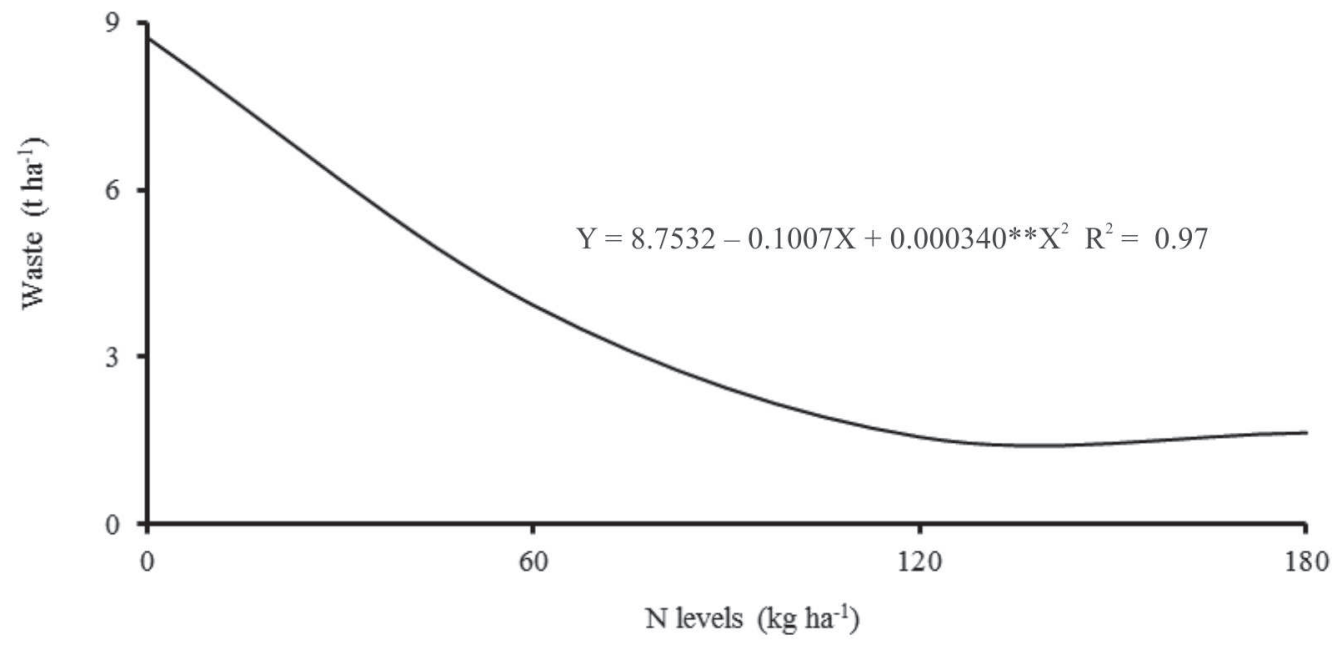

Figure 2. Waste (non-commercial yield) of onion bulbs according to N levels. Petrolina-PE, Embrapa Semiárido, 2009.

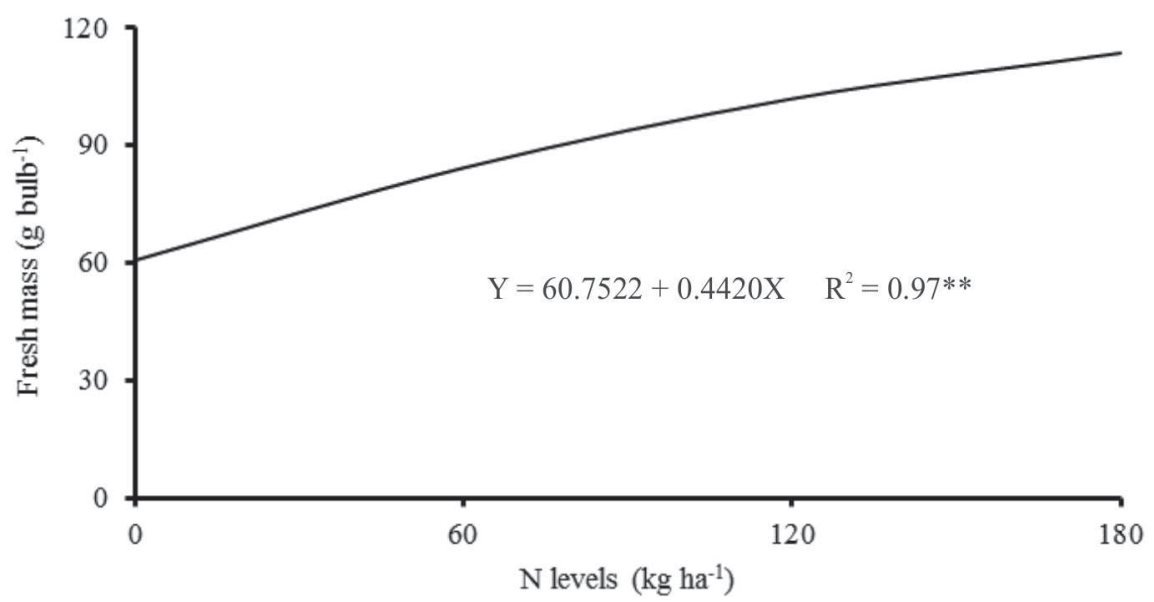

Figure 3. Onion bulbs fresh mass according to N levels. Petrolina-PE, Embrapa Semiárido, 2009. 
Table 1. Classification (potassium (K) level classes, \%), according to cross diameter of onion bulbs in function of the N levels (N). Petrolina - PE, Embrapa Semiárido, 2009

\begin{tabular}{llc}
\hline Characteristic & Regression equations & $\mathbf{R}^{2}$ \\
\hline \multirow{3}{*}{ Class 2} & $\mathrm{~N}: \mathrm{K}(0) \mathrm{Y}=47.8641-0.1194 * * \mathrm{X}$ & 0.75 \\
& $\mathrm{~N}: \mathrm{K}(90) \mathrm{Y}=50.8193-0.4686 \mathrm{X}+0.001836 * * \mathrm{X}^{2}$ & 0.99 \\
\hline \multirow{3}{*}{ Class 3} & $\mathrm{~N}: \mathrm{K}(180) \mathrm{Y}=55.2595-0.1691 * \mathrm{X}$ & 0.76 \\
& $\mathrm{~N}: \mathrm{K}(0) \mathrm{Y}=40.6697+0.0770 * * \mathrm{X}$ & 0.65 \\
\hline \multirow{3}{*}{ Class 4} & $\mathrm{~N}: \mathrm{K}(90) \mathrm{Y}=39.6007+0.3970 \mathrm{X}-0.001655^{* * \mathrm{X}^{2}}$ & 0.97 \\
& $\mathrm{~N}: \mathrm{K}(180) \mathrm{Y}=32.9212-0.1162+0.001600 * * \mathrm{X}^{2}$ & 0.79 \\
\hline
\end{tabular}

*** Significant at 1 and $5 \%$ probability by the $\mathrm{F}$ test and Non-significant.

consequent reduction in the production of smaller size bulbs (class 2). Such result is well evidenced when positive or negative linear effects were achieved. The literature reports an antagonism between these elements; however, the results suggest an additional response, in which $\mathrm{N}$ is the main factor that positively affects the production of larger diameter bulbs. These results corroborate the statements of May et al. (2007), who concluded that a more expressive application of nitrogen, in terms of relevance to the response to the application of potassium fertilization, probably due to their different metabolic functions.

The positive results obtained with nitrogen and potassium fertilization on onion crop can be justified by the fact that nitrogen is absorbed in large amounts, surpassed only by potassium (Porto et al., 2007, May et al., 2008) and it can be found in organic compounds such as amino acids and nucleic acids and takes place in diverse vital physiological processes to plants - ion absorption, photosynthesis, respiration, and cell differentiation and multiplication and inheritance (Epstein \& Bloom, 2004). Moreover, because potassium integrates different biochemical functions in the physiological processes, whether in translocation of sugars (translocation and storage of photosynthesis assimilates), in the respiration, in the opening and closing of stomata in osmotic regulation (maintaining the osmotic potential and ionic balance) or as activator of more than 60 enzymes related to these processes (Malavolta, 2006; Epstein \& Bloom, 2006).

Because of the positive results in commercial and noncommercial (waste) productivity, fresh mass and classification of bulbs (diameter) the doses, in interaction, of $172.6 \mathrm{~kg} \mathrm{ha}^{-1} \mathrm{~N}$ (which promoted greater yields) and 90 $\mathrm{kg} \mathrm{ha}^{-1} \mathrm{~K}_{2} \mathrm{O}$ (which provided better responses in terms of classification of commercial bulbs) are suggested as a way to unify a recommendation for fertilization of Vale Ouro IPA-11 cultivar. Such recommendation is the most suitable for cultivation under conditions in the São Francisco Valley.

\section{CONCLUSION}

The increase in the levels of nitrogen increased fresh mass yield of of bulbs and reduced the yields of non-commercial bulbs (waste).

The $\mathrm{N} x \mathrm{~K}$ interaction provided the highest yield of intermediate diameter and larger caliber bulbs and the reduction of smaller bulbs.

Levels of $172.6 \mathrm{~kg} \mathrm{ha}^{-1}$ of $\mathrm{N}$ and $90 \mathrm{~kg} \mathrm{ha}^{-1}$ of $\mathrm{K}_{2} \mathrm{O}$, in function of the different characteristics evaluated, may be indicated as those that provided the best responses to the crop under the conditions found in the São Francisco Valley.

\section{AKNOWLEDGEMENTS}

The authors thank CNPq for the aid granted to experiment (Proc. 474186/2006-7).

\section{REFERENCES}

Akhtar ME, Bashir K, Khan MZ \& Khoklar KM (2002) Effect of potash application on yield of different varieties of onion (Allium cepa L.). Asian Journal of Plant Science 1:324-325.

Azevedo PV, Sousa IF, Silva BB \& Silva VPR (2006) Water-use efficiency of dwarf-green coconut (Cocos nucifera L.) orchards in Northeast Brazil. Agricultural Water Management $1: 259-264$.

Diaz-Perez JC, Purvis AC \& Paulk JT (2003) Bolting, yield, and bulb decay of sweet onion as affected by nitrogen fertilization. Journal American Society Horticultural Science, 128:144-149.

Epstein E \& Bloom AJ (2006) Nutrição mineral de plantas: princípios e perspectivas. $2^{a}$ ed. Londrina, Planta. 403p.

Ferreira DF (2010) SISVAR. Sistema de Análise de Variância. Versão 5.3. Lavras, UFLA. CD ROM.

Filgueira FAR (2008) Novo manual de olericultura: agrotecnologia moderna na produção e comercialização de hortaliças. $3^{\mathrm{a}}$ ed. Viçosa, Editora UFV. 421p.

Ghaffoor A, Jilani MS, Khaliq G \& Waseem K (2003) Effect of different NPK levels on the yield of three onion (Allium cepa L.) varieties. Asian Journal Plant Sciences, 2:342-346. 
Hussaini MA, Amans EB \& Ramalan AA (2000) Yield, bulb size distribution, and storability of onion (Allium cepa L.) under different levels of $\mathrm{N}$ fertilization and irrigation regime. Tropical Agriculture, 77:145-149.

IBGE - Instituto Brasileiro de Geografia e Estatística (2012) Levantamento Sistemático da Produção Agrícola. Rio de Janeiro, IBGE. p.01-88.

Kumar A, Singh R \& Chchillar RK (2001) Influence of nitrogen and potassium application on growth, yield and nutrient uptake by onion (Allium cepa). Indian Journal Agronomy 46:742-746.

Lee JT, Ha IJ, Lee CJ, Moon JS \& Cho YC (2003) Effect of N, $\mathrm{P}_{2} \mathrm{O}_{5}$, and $\mathrm{K}_{2} \mathrm{O}$ application rates and top dressing time on growth and yield of onion (Allium cepa L.) under spring culture in low land. Korean Journal Horticultural Science and Technology, $21: 260-266$

Malavolta E (2006) Manual de nutrição mineral de plantas. São Paulo, Agronômica Ceres. 638p.

Mandira C \& Khan AH (2003) Effect of nitrogen and potassium on growth, yield and yield attributes of onion. New Agriculturist, 14:09-11

May A, Cecílio Filho AB, Porto DRQ, Vargas PF \& Barbosa CB (2007) Produtividade de híbridos de cebola em função da população de plantas e da fertilização nitrogenada e potássica. Horticultura Brasileira, 25:53-59.

May A, Cecílio Filho AB, Porto DRQ, Vargas Forlan P \& Barbosa JC (2008) Acúmulo de macronutrientes por duas cultivares de cebola produzidas em sistema de semeadura direta. Bragantia, 67:507-512.
Mohanty BK \& Das JN (2001) Response of rabi onion cv. Nasik Red to nitrogen and potassium fertilization. Vegetable Science, 28:40-42.

Neeraja G, Reddy KM, Reddy MS \& Rao VP (2001) Influence of irrigation and nitrogen levels on bulb yield, nutrient uptake an nitrogen use efficiencies in rabi onion (Allium cepa). Indian Journal Agricultural Sciences, 7:109-111.

Porto DRQ, Cecilio Filho AB, May A \& Vargas PF (2007) Acúmulo de macronutrientes pela cultivar de cebola "Superex" estabelecida por semeadura direta. Ciência Rural, 37:949-955.

Resende GM, Costa ND \& Pinto JM (2009) Produtividade e qualidade pós-colheita de cebola adubada com doses crescentes de nitrogênio e potássio. Horticultura Brasileira, 26:388-392.

Santos HG, Jacomine PKT, Anjos LHC, Oliveira VA, Oliveira JB, Coelho MR, Lumbreras JF \& Cunha TJF (2006) Sistema brasileiro de classificação de solos. $2^{\mathrm{a}}$ ed. Rio de Janeiro, Embrapa Solos. 306p.

Shock CC, Erik BGF \& Saunders LM (2004) Plant population and nitrogen fertilization for subsurface drip-irrigated onion. HortScience, 39:1722-1727.

Singh S, Yadav PK \& Singh B (2004) Effect of nitrogen and potassium on growth and yield of onion (Allium cepa L.) cv. Pusa Red. Haryana Journal Horticultural Sciences, 33:308-309.

Yadav GL, Sharma PK \& Kumar S (2003) Response of kharif onion to nitrogen and potash fertilization. News Letter National Horticultural Foundation, 23:4-6. 